\title{
Biological Pre-treatment of Poultry Slaughterhouse Wastewater
}

\author{
Cebisa T. Mdladla ${ }^{\mathrm{a}, \mathrm{b}}$, Honeil B. Meyo ${ }^{\mathrm{a}, \mathrm{b}}$, Moses Basitere ${ }^{\mathrm{a}, \mathrm{b}}$ and Seteno K. O. Ntwampe $\mathrm{N}^{\mathrm{a}, \mathrm{b}}$
}

\begin{abstract}
Poultry slaughterhouse wastewater (PSW) is usually disposed of by discharging it into watercourses, municipal wastewater treatment works (WWTWs), or by scattering it on grass and croplands. However, the hazardous nature of the PSW makes it injurious to human health and the environment. As a result, the South African Government has established a Waste Discharge Charge System (WDCS), which is based on the 'polluter pays' principle, as a means to encourage industrial waste dischargers to reduce their waste and use water resources optimally. Therefore, the poultry industry is required to adopt the latest technologies that will reduce freshwater consumption and increase reuse practices to achieve zero effluent discharges. This paper will present wastewater treatment options available, and give motivation as to why Sumo, which is a wastewater process simulator, should be applied to evaluate the performance of an anaerobic bioreactor.
\end{abstract}

Keywords-Bioflocculants, biosurfactants, expanded granular sludge bed reactor and pre-treatment.

\section{INTRODUCTION}

The agricultural sector particularly the poultry industry is exploring alternative means to reduce water wastage due to recent water shortages experienced in South Africa [1]. The poultry slaughterhouse industry has been noted to be one of the highest contributors to the consumption of potable water, which results in generation of high volumes of wastewater. Processing of one live bird requires an estimated average of about 26.5 litres of potable water and the greater percentage of the consumption is attributed to evisceration and sanitation of equipment [2], [3].

The organic load contribution comes from different materials such as fat, oil and grease (FOG), lard, blood, undigested food, loose meat, paunch, colloidal particles suspended materials and soluble proteins [4]. As a result, poultry processing wastewater has high concentrations of biological oxygen demand (BOD), chemical oxygen demand (COD), total suspended solids (TSS) form slaughtering, fats oils and grease (FOGs) and cleaning activities which filters into drinking reservoirs [5]. The

Manuscript received October 14 2019. This work was supported in part by Cape Peninsula University of Technology (CPUT) under URF RK16 and Bioresource Engineering Research Group (BioERG) under RK45.

${ }^{a}$ Department of Chemical Engineering, Faculty of Engineering and Built Environment, Cape Peninsula University of Technology, P.O. Box 1906, Bellville, 7535, South Africa,.

${ }^{\mathrm{b}}$ Bioresource Research Group, Cape Peninsula University of Technology, P.O. Box 652, Cape Town, 8000 South Africa, treatment process needs to be intensified by poultry product producing industries prior to water being discharged to avert the excessive usage of water, reduce the high concentration of wastewater pollutants escaping into streams and rivers [6], to comply with the stringent regulatory environmental rules, relieve the water supply insecurities and the eminent water scarcity in South Africa [1].

The treatment disposal of poultry slaughterhouse wastewater (PSW) is both a public health and an economic necessity [7]. The poultry industry will benefit from the effective wastewater treatment by being able to reduce potable water demand and minimize the quantity of wastewater generated for disposal [3]. Three distinct treatment systems have been employed by the poultry industry depending on the treatment process required. These options include physical, chemical and biological treatment systems and each system type possess unique treatment advantages and operational difficulties [6].

This review will focus on the use of biological systems to reduce sludge formation and accumulation of FOGs prior to treatment of PSW in the Expanded Granular Sludge Bed (EGSB) reactor.

\section{Material AND ReACtor Design}

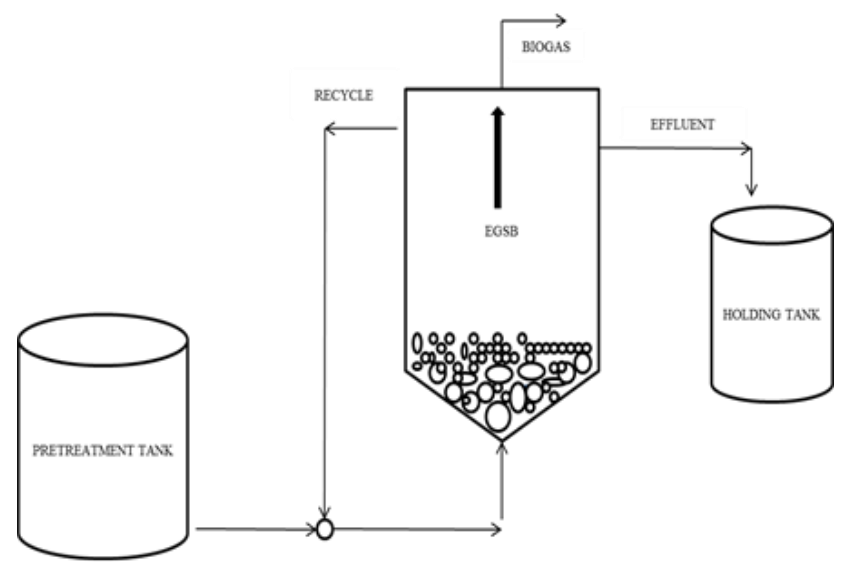

Fig. 1. A schematic diagram of the PSW treatment process

The bioreactor system consists of a pretreatment tank for the degradation of organic soluble which would otherwise cause clogging up of the EGSB reactor. The EGSB reactor is also fitted with a recycling step to help prevent sludge washout and clogging up of the EGSB reactor. The effluent is collected in a holding tank and further testing for BOD, COD, TSS and FOGs will be conducted from the effluent. 


\section{DISCUSSION}

\section{A. Pretreatment using Biological Processes}

A significant volume of highly polluted wastewater is generated by poultry slaughterhouses during the slaughtering stage and periodic washing of residual particles, which results in significant variations in the biodegradable organic matter concentration. Therefore, an efficient treatment process should be carried by poultry slaughterhouses to treat the wastewater before it is discharged into receiving water bodies and to subsequently prevent severe environmental pollution [4]. Several treatment methods have been reported for PSW over the past few decades. Biological (aerobic and anaerobic) treatment methods have been traditionally used for slaughterhouse wastewater treatment. The ability of different bacterial strains to produce a variety of by-products which are either beneficial or detrimental to scientific research has enhanced the need to better understand the impact of harnessing of biological processes instead of chemical or physical processes [8]. Anaerobic bacteria are responsible for the fermentation of methane gas from sewage sludge, they facilitate the decomposition of macromolecular organic matter into simpler compounds, and therefore, they play an important role in the wastewater treatment processes [9]. Anaerobic treatment processes are often impaired because of accumulation of FOGs and SS which in turn lead to reduction in the methanogenic activity and biomass washout.

Aerobic treatment has been used to pretreat PSW in processes such as the Dissolved Air Floatation (DAF) pretreatment tank [10]. This treatment process requires high energy consumption for aeration and generates large amounts of sludge, moreover, as the pretreated water is transferred into the bioreactor the aerobic bacteria which initially had access to oxygen in the pretreatment tank is unable to continue replicating in oxygen-depleted bioreactors and subsequently die. This review seeks to illustrate that a pretreatment step is required for efficient digestion of biodegradable organic matter. Bacterial cultures with bioremedial activity and can survive in both aerobic as well as anaerobic conditions are most suitable for pretreatment of PSW as they remain active under both conditions and would further ensure that the remediation that occurs in the pretreatment tank continues to occur in the bioreactor which is oxygen-depleted.

\section{B. Flocculation in PSW Pretreatment}

Flocculation precipitation has been commonly used for the gradual accumulation of colloids, cells and suspended solids in the treatment of drinking water, fermentation processes, production of food and treatment of wastewater [11]. There are distinct groups in which flocculants are classified into, namely: 1) organic synthetic flocculants such as polyacrylamide derivatives, 2) inorganic synthetic flocculants such as polyaluminium chloride and 3) naturally occurring flocculants such as chitosan. Organic and inorganic synthetic flocculants are widely used in industrial fields for their cost efficiency and cost-effectiveness, but their use may also result in some environmental and health issues [12]. Health issues caused by these flocculants may include; Alzheimer's disease [13], which is caused by Aluminum salts, as well as the formation of neurotoxic and carcinogenic acrylamide monomers that are harmful to humans and the environment [14]. This has therefore sparked renewed interest in a less toxic method of flocculation namely naturally occurring bioflocculants for the precipitation of organic matter.

Bioflocculants are non-toxic and biodegradable extracellular biopolymeric substances secreted by algae, yeast, and bacteria [15]. They rely on the difference in composition and properties of polysaccharides and proteins which lead to differences in the charge of bioflocculants [16]. In general, bioflocculants cause the aggregation of particles and cells by bridging and charge neutralization [15]. Bioflocculant composition consists of macromolecular substances such as protein and polysaccharide-protein [5], [17] and is dependent on the type of bioflocculants producing microorganisms (BPMs) [18]. Due to these properties and the lack of secondary pollution of their degradative intermediates [15], bioflocculants have been identified as a possible alternative to flocculation which requires the use of chemicals including ferric chloride, polyaluminium chloride and polyacrylamide [19]. Table I below provides a list of bioflocculant producing microorganisms, their preferred energy source as well as their mode of action.

TABLE I: DEPICTS THE DIFFERENT TYPES OF BIOFLOCCULANT PRODUCING MICROORGANISMS, THEIR PREFERRED ENERGY SOURCE AND THEIR MODE OF ACTION.

\begin{tabular}{lll} 
Bioflocculants & Energy source & Mode of action \\
\hline Gyrodinimimpudicum KG03 & $\begin{array}{l}\text { Acidic } \\
\text { heteropolysaccharide }\end{array}$ & $\begin{array}{l}\text { Galactose and } \\
\text { uronic acid } \\
\text { production }\end{array}$ \\
Nannocystis species Nu-2 & Glycoprotein & $\begin{array}{l}\text { Bleaching acid red } \\
\text { and direct emerald } \\
\text { blue }\end{array}$ \\
Rhodococcuserythropolis & Proteins & $\begin{array}{l}\text { Enzymatic } \\
\text { digestion }\end{array}$ \\
\hline \hline
\end{tabular}

\section{Pretreatment with Biosurfactants}

The importance of surfactants in household and industrial applications is undeniable and they have been used to confer excellent detergency, emulsifying, foaming and dispersing traits [20]. Surfactants are amphipathic molecules that have both hydrophobic and hydrophilic moieties that partition preferentially at the interphases such as liquid/liquid, gas/liquid or solid/liquid. Surfactants also have different degrees of polarity and hydrogen bonding, as such surfactants are mostly chemically synthesized and petroleum-based [21].

The environmental implications of using surfactants such as toxicity, biodegradability, ecological acceptance and affordability encouraged the search trend towards using environmentally friendly technologies [22]. Biosurfactants have therefore gained much attention because they exhibit environmental ecological advantages. Biosurfactants produced by microorganisms in the environment assist in the uptake of 
hydrocarbons as a carbon source. This is done by either the microorganism changing its cell surface so that the contaminant can be absorbed or by making available the hydrocarbon by releasing biosurfactants into the environment. Because of their hydrocarbon dissolving agents, biosurfactants were identified as potential replacements for synthetic surfactants in food, oil and pharmaceutical industries [23]. Table II below gives a comparison of the advantages and disadvantages of using chemical and biological surfactants.

TABLE II. A COMPARISON BETWEEN CHEMICAL AND BIOLOGICAL SURFACTANTS

\begin{tabular}{lll}
\hline \hline & Advantages & Disadvantages \\
\hline Chemical & $\begin{array}{l}\text { Cost-effective, High } \\
\text { flocculating activity } \\
\text { Environmentally friendly, } \\
\text { Biological } \\
\text { biodegradable, free risk of } \\
\text { secondary pollution, non-toxic } \\
\text { and harmless to humans, } \\
\text { animals and environment }\end{array}$ & $\begin{array}{l}\text { High production costs and } \\
\text { high dosage requirements }\end{array}$ \\
\hline \hline
\end{tabular}

Biosurfactants can be used in a range of industrial applications including, crude oil drilling, lubricants, bioremediation of pollutants, health care, enhanced oil recovery and food processing [24]. Most biosurfactants are complex molecules comprising of different structures including glycolipids, polysaccharides-protein complex, lipopeptides, phospholipids and fatty acids [25] and they are classified based on their chemical composition, their mode of action and the microorganisms that produce them [23]. Table III list microorganisms which have been identified to produce biosurfactants as well as their lipo-structures or groups.

TABLE III. BIOSURFACTANT PRODUCING MICROORGANISMS [23].

\begin{tabular}{ll}
\hline \hline Microorganism & Biosurfactant lipo-structures or group \\
\hline Pseudomonas aeruginosa & Rhamnolipids \\
Acinetobacter calcoacerticus & Lipopolysaccharides (biodispersant) \\
Bacillus subtilise & Lipopetides and lipoproteins (surfactin) \\
Bacillus licheniformis & Lipopeptides (lichenysin) \\
Mycobacterium species & Trehalolipids \\
Nocardia species & Trehalolipids \\
Tsukamurella species & Di and oligosaccharide lipids \\
\hline \hline
\end{tabular}

Biosurfactant producing microorganisms are mainly isolated from sites that are or were contaminated with wastewater, contaminated soils, petroleum hydrocarbons and effluents. They have the ability to grow on substrates considered to be potentially noxious for other non-biosurfactant-producing microorganisms. Biosurfactants play a physiologic role in increasing bioavailability of hydrophobic molecules, which are involved in cellular signalling and differentiation processes, which facilitate the consumption of carbon sources present in the poultry wastewater [23].

\section{CONCLUSION AND RECOMMENDATIONS}

Biosurfactants are of particular interest due to their ability to decrease surface tension in waste as well as their ability to degrade hydrocarbons. PSW contains high concentrations of FOGs which are high in hydrocarbons and thus provide a consistent supply of carbon source for biosurfactant producing bacteria. The use of bioflocculants for coagulation of organic waste through the formation of flocs and biosurfactants to reduce surface tension and hydrolyze hydrocarbons within the pretreatment tank can be employed symbiotically to help reduce the formation of sludge, prevent the sedimentation of the formed flocs and thus allowing the filtration of dissolved organic solubles from the pretreatment tank to the bioreactor. However, no studies have been conducted to investigate if bioflocculant and biosurfactant producing bacteria can be used symbiotically as a pre-treatment option for anaerobic bioreactors. This review probes for the use as a combined biological pretreatment option and to quantitatively determine its performance in reducing the accumulation of organic load in poultry slaughterhouse wastewater prior to treatment in a bioreactor.

\section{ACKNOWLEDGMENT}

The authors wish to acknowledge the Cape Peninsula University of Technology (CPUT) as well as the Bioresource Engineering Research Group for the financial support without which this research would not have been successful. The supervision, patience and persistence from Dr Moses Basitere and Prof Seteno Ntwampe have been the cornerstone for the completion of this paper.

\section{REFERENCES}

[1] M. Basitere, Y. Williams, M. S. Sheldon, S. K. O. Ntwampe, and D. De Jager. "Performance of an expanded granular sludge bed ( EGSB ) reactor coupled with anoxic and aerobic bioreactors for treating poultry slaughterhouse wastewater," vol. 11, no. 1, pp. 86-92, 2016. https://doi.org/10.2166/wpt.2016.013

[2] D. Yordanov, 2010. "Preliminary study of the efficiency of ultrafiltration treatment of poultry slaughterhouse wastewater," Bulg. J. Agric. Sci., vol. 16, no. 6, pp. 700-704, 2010.

[3] R. Y. Avula, H. M. Nelson, and R. K. Singh, 2009. "Recycling of poultry process wastewater by ultrafiltration," Innov. Food Sci. Emerg. Technol., vol. 10, no. 1, pp. 1-8, 2009. https://doi.org/10.1016/j.ifset.2008.08.005

[4] W H. A. Aziz, N. Nasuha, A. Puat, and M. Y. D. Alazaiza. "Poultry Slaughterhouse Wastewater Treatment Using Submerged Fibers in an Attached Growth Sequential Batch Reactor," pp. 1-12, 2018. https://doi.org/10.3390/ijerph15081734

[5] W. Y. Lu, T. Zhang, D. Y. Zhang, C. H. Li, J. P. Wen, and L. X. Du. "A novel bioflocculant produced by Enterobacter aerogenes and its use in defecating the trona suspension," Biochem. Eng. J., vol. 27, no. 1, pp. $1-7,2005$. https://doi.org/10.1016/j.bej.2005.04.026

[6] R. Rajakumar, T. Meenambal, J. R. Banu, and I. T. Yeom. "Treatment of poultry slaughterhouse wastewater in upflow anaerobic filter under low upflow velocity," Int. J. Environ. Sci. Technol., vol. 8, no. 1, pp. $149-158,2011$. https://doi.org/10.1007/BF03326204

[7] C. F. Bustillo-Lecompte, M. Mehrvar, and E. Quiñones-Bolaños. "Combined anaerobic-aerobic and UV/H2O2 processes for the treatment of synthetic slaughterhouse wastewater," J. Environ. Sci. Heal. - Part A Toxic/Hazardous Subst. Environ. Eng., vol. 48, no. 9, pp. 1122-1135, 2013.

https://doi.org/10.1080/10934529.2013.774662 
[8] M. Quezada, G. Buitrón, I. Moreno-Andrade, G. Moreno, and L. M. López-Marín. "The use of fatty acid methyl esters as biomarkers to determine aerobic, facultatively aerobic and anaerobic communities in wastewater treatment systems," FEMS Microbiol. Lett., vol. 266, no. 1, pp. 75-82, 2007 https://doi.org/10.1111/j.1574-6968.2006.00509.x

[9] M. Cyprowski, A. Stobnicka-Kupiec, A. Ławniczek-Wałczyk, A. Bakal-Kijek, M. Gołofit-Szymczak, and R. L. Górny. "Anaerobic bacteria in wastewater treatment plant," Int. Arch. Occup. Environ. Health, vol. 91, no. 5, pp. 571-579, 2018. https://doi.org/10.1007/s00420-018-1307-6

[10] C. Dlangamandla, S. K. O. Ntwampe, and M. Basitere. "A bioflocculant-supported dissolved air flotation system," Water Sci. Technol., vol. 78, no. 2, pp. 452-458, 2018. https://doi.org/10.2166/wst.2018.324

[11] I. L. Shih, Y. T. Van, L. C. Yeh, H. G. Lin, and Y. N. Chang. "Production of a biopolymer flocculant from Bacillus licheniformis and its flocculation properties," Bioresour. Technol., vol. 78, no. 3, pp. 267-272, 2001. https://doi.org/10.1016/S0960-8524(01)00027-X

[12] H. Liu, F. Cheng, and D. Wang. "Interaction of ozone and organic matter in coagulation with inorganic polymer flocculant-PACl: Role of organic components," Desalination, vol. 249, no. 2, pp. 596-601, 2009. https://doi.org/10.1016/j.desal.2008.06.032

[13] A. Campbell. "The potential role of aluminium in Alzheimer's disease," Nephrol. Dial. Transplant., vol. 17, no. SUPPL. 2, pp. 17-20, 2002. https://doi.org/10.1093/ndt/17.suppl 2.17

[14] C. Rudén. "Acrylamide and cancer risk - Expert risk assessments and the public debate," Food Chem. Toxicol., vol. 42, no. 3, pp. 335-349, 2004. https://doi.org/10.1016/j.fct.2003.10.017

[15] H. Salehizadeh and S. Shojaosadati. "Extracellular biopolymeric flocculants," Biotechnol. Adv., vol. 19, no. 5, pp. 371-385, 2001 https://doi.org/10.1016/S0734-9750(01)00071-4

[16] S. Bala Subramanian, S. Yan, R. D. Tyagi, and R. Y. Surampalli. "Extracellular polymeric substances (EPS) producing bacterial strains of municipal wastewater sludge: Isolation, molecular identification, EPS characterization and performance for sludge settling and dewatering," Water Res., vol. 44, no. 7, pp. 2253-2266, 2010. https://doi.org/10.1016/j.watres.2009.12.046

[17] Y. Zheng, Z. L. Ye, X. L. Fang, Y. H. Li, and W. M. Cai. "Production and characteristics of a bioflocculant produced by Bacillus sp. F19," Bioresour. Technol., vol. 99, no. 16, pp. 7686-7691, 2008. https://doi.org/10.1016/j.biortech.2008.01.068

[18] A. H. R. Aljuboori, A. Idris, N. Abdullah, and R. Mohamad. "Production and characterization of a bioflocculant produced by Aspergillus flavus," Bioresour. Technol., vol. 127, pp. 489-493, 2013. https://doi.org/10.1016/j.biortech.2012.09.016

[19] Z. Li, S. Zhong, H. Lei, R. Chen, Q. Yu, and H. L. Li. "Production of a novel bioflocculant by Bacillus licheniformis X14 and its application to low temperature drinking water treatment," Bioresour. Technol., vol. 100 , no. 14 , pp. $3650-3656,2009$. https://doi.org/10.1016/j.biortech.2009.02.029

[20] K. V. Rajeshwari, M. Balakrishnan, A. Kansal, K. Lata, and V. V. N. Kishore. "State-of-the-art of anaerobic digestion technology for industrial wastewater treatment," Renew. Sustain. energy Rev., vol. 4, no. 2, pp. 135-156, 2000. https://doi.org/10.1016/S1364-0321(99)00014-3

[21] I. M. Banat. "97/02677 Microbial production of surfactants and their commercial potential," Fuel Energy Abstr., vol. 38, no. 4, p. 221, 1997. https://doi.org/10.1016/S0140-6701(97)84559-6

[22] R. Makkar and S. Cameotra. "An update on the use of unconventional substrates for biosurfactant production and their new applications," Appl. Microbiol. Biotechnol., vol. 58, no. 4, pp. 428-434, 2002. https://doi.org/10.1007/s00253-001-0924-1

[23] C. I. Sáenz-Marta, M. de L. Ballinas-Casarrubias, B. E. Rivera-Chavira, and G. V. Nevárez-Moorillón. "Biosurfactants as Useful Tools in Bioremediation," Adv. Bioremediation Wastewater Polluted Soil., 2015. https://doi.org/10.5772/60751

[24] I. M. Banat, R. S. Makkar, and S. S. Cameotra. "Potential commercial applications of microbial surfactants," Appl. Microbiol. Biotechnol., vol. 53 , no. 5, pp. 495-508, 2000. https://doi.org/10.1007/s002530051648
[25] M. Nitschke and G. M. Pastore. "Production and properties of a surfactant obtained from Bacillus subtilis grown on cassava wastewater," Bioresour. Technol., vol. 97, no. 2, pp. 336-341, 2006. https://doi.org/10.1016/j.biortech.2005.02.044

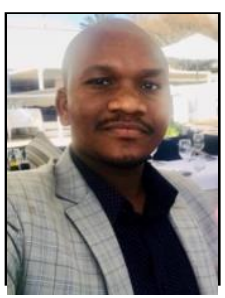

Cebisa Mdladla was born and grew up in Willowvale in the Eastern Cape, South Africa. He completed his undergraduate diploma in Biotechnology at Cape Peninsula University of Technology (CPUT), Cape Town, South Africa in 2009. His BTech, also in Biotechnology, was completed at Tshwane University of Technology (TUT), Tshwane, South Africa in 2012 and he is currently pursuing his Masters in Chemical Engineering at CPUT focusing on the pretreatment of poultry slaughterhouse wastewater with biological treatment systems.

He is currently working at TASK Applied Sciences, in Cape Town, South Africa, as a Laboratory Supervisor, prior to this job; he held a Laboratory Technologist position in the same company and has been with the company since 2012.

Mr Mdladla will be attending the $16^{\text {th }}$ Johannesburg International Conference on Science, Engineering, Technology and Waste Management (SERWM-19) in November 2019, where he will be presenting a paper on The Biological Pretreatment of Poultry Slaughterhouse Wastewater. The conference committee has invited him to submit the aforementioned paper to the Bioresource Technology Journal for publishing. 